\title{
Lung cancer: the global killer
}

\begin{abstract}
Lung cancer is the number one cancer in the world for several decades. There are estimated to be 1.8 million new cases in 2012 (12.9\% of the total), 58\% of which occurred in the less developed regions. The disease remains as the most common cancer in men worldwide (1.2 million, $16.7 \%$ of the total) ${ }^{1}$ There were 14.1 million new cancer cases, 8.2 million cancer deaths and 32.6 million people living with cancer (within 5 years of diagnosis) in 2012 worldwide $^{2}$ Lung cancer remains a major worldwide health problem, accounting for more than a sixth of cancer deaths. ${ }^{3}$
\end{abstract}

Volume 5 Issue 2 - 2018

\section{Jyoti Priyadarshini Shrivastava',Alok Shrivastava ${ }^{2}$}

'Departement of Pathology, Gajra Raja Medical College, India

${ }^{2}$ Consultant Orthopedician, District Hospital, India

Correspondence: Jyoti Priyadarshini Shrivastava, Associate Professor, Departement of Pathology, Gajra Raja Medical

College, Gwalior, Madhya Pradesh, India, Email: drpriyajyoti22@ gmail.com

Received: December II, 2017| Published: March 08, 2018

\section{Introduction}

Lung cancer, also known as lung carcinoma, ${ }^{4}$ is a malignant lung tumor characterized by uncontrolled cell growth in tissues of the lung. ${ }^{5}$ This growth can spread beyond the lung by the process of metastasis into nearby tissue or other parts of the body. ${ }^{6}$ Incidence and mortality attributed to lung cancer has risen steadily since the 1930 s, predominantly due to the popularity of cigarette smoking. ${ }^{7,8}$ Sir Richard Doll and Austin Hill's landmark article in 1950 described mounting evidence that lung cancer was associated with cigarette smoking. ${ }^{79}$ Number and duration of smoking are directly proportional to incidence of lung cancer.

In the past 100 years, lung cancer has therefore been transformed from a rare disease ${ }^{10}$ into a global problem. ${ }^{7,8}$ Efforts to fight the deadly disease have lead to a greater understanding of the varied and multifactorial etiology of lung cancer along with histologic and molecular characteristics and classification of individual lung tumors. Histologically and Morphologically Lung cancer is primarily divided into Non Small cell Lung cancer(NSCLC) and Small cell Lung cancer(SCLC). The most common symptoms are coughing (including coughing up blood), weight loss, shortness of breath, and chest pains. ${ }^{11}$.Genetic susceptibility to lung cancer is under study. The Four genes are: EGFR, KRAS, the PI3K-Akt-mTOR complex, and TITF $1 .{ }^{12}$ Lung being commonest site of metastasis, Metastatic Lung cancer is commoner than primary tumour. November is celebrated as Lung cancer Awareness month. A white ribbon brings awareness to lung cancer. Despite all efforts Lung cancer remains King killer amongst men and women globally.

\section{Research directions}

Current research directions for lung cancer treatment include immunotherapy, which encourages the body's immune system to attack the tumor cells, epigenetics, and new combinations of chemotherapy and radiotherapy, both on their own and together. Many of these new treatments work through immune checkpoint blockade, disrupting cancer's ability to evade the immune system. ${ }^{13}$

\section{Conclusion}

Lung cancer is associated with known tobacco, smoke and environmental aetiology. There is scope to reduce incidence by generating awareness. Advancement of science has lead to understanding of lung cancer biology, genetic susceptibility hence promoting development of targeted therapies and providing prognostic predictors of treatment response and outcome.

\section{Acknowledgements}

None.

\section{Conflict of interest}

None.

\section{References}

1. http://globocan.iarc.fr/old/FactSheets/cancers/lung-new.asp

2. http://globocan.iarc.fr/Pages/fact_sheets_cancer.asp

3. Hoffman PC, Mauer AM, Vokes EE. Lung cancer. Lancet. 2000;355(9202):479-85.

4. Lung Carcinoma: Tumors of the Lungs. Merck Manual Professional Edition. 2007.

5. Non-Small Cell Lung Cancer Treatment -Patient Version (PDQ $\left.{ }^{\circledR}\right)$. NCI; 2016.

6. Falk S, Williams C. Chapter 1. Lung Cancer-the facts. 3rd ed. Oxford University Press; 2010. p. 3-4.

7. Ridge CA, McErlean AM, Ginsberg MS. Epidemiology of Lung Cancer. Semin Intervent Radiol. 2013;30(2):93-98.

8. American Cancer Society. Cancer Facts and Figures. Atlanta, GA: 2012.

9. Doll R, Hill AB. Smoking and carcinoma of the lung; preliminary report. BMJ. 1950;2(4682):739-748.

10. Adler I. Primary malignant growths of the lungs and bronchi. New York, NY: Longmans, Green; 1912.

11. Horn L, Lovly CM, Johnson DH. Chapter 107: Neoplasms of the lung. In: Kasper DL, Hauser SL, editors. Harrison's Principles of Internal Medicine. 19th ed. McGraw-Hill; 2015.

12. Herbst RS, Heymach JV, Lippman SM, Lung Cancer. $N$ Engl J Med. 2008;359(13):1367-1380.

13. Brahmer JR. Immune checkpoint blockade: the hope for immunotherapy as a treatment of lung cancer? Seminars in oncology. 2014;41(1):126-32. 